\title{
Antioxidants Status in Acute Lymphoblastic Leukemic Patients
}

\author{
M. E. El-Sabagh ${ }^{1}$, K. S. Ramadan ${ }^{2}$, I. M. A. El-slam ${ }^{3}$, A. M. Ibrahim ${ }^{3}$ \\ ${ }^{1}$ Biochemistry Department, Faculty of Science, Ain Shams University, Cairo, Egypt \\ ${ }^{2}$ Department of Biochemistry, Faculty of Girls Science, King Abdulaziz University, Jeddah, Saudi Arabia \\ ${ }^{3}$ Cancer Biology Department, National Cancer institute, Cairo University
}

\begin{abstract}
ALL is the most common form of childhood cancer. Sufferers are treated with chemotherapy, which is associated with the production of free radicals. The aim of this study was to investigate the oxidative stress markers and some antioxidants status among Acute Lymphoblastic Leukemia patients. This study included 40 children newly diagnosed ALL before chemotherapy (mean age, $8.2 \pm 2$ ) compared to 20 healthy controls (mean age, $7.6 \pm 1.4$ ). The same of 40 patients of ALL undergoing chemotherapy treatment for 3 months. Oxidative stress, blood antioxidants status, kidney and liver profiles were measured in all groups. Our results showed that Antioxidants levels and $\mathrm{Hb}$ were significant decreased in ALL patients $(\mathrm{P}<0.05)$ compared to control group, then antioxidants levels were more significant decreasing after ALL patients undergoing chemotherapy. In contrast MDA, 8dG, leukocytes count and Lymphoblast were significant increased $(\mathrm{P}<0.05)$ compared to control group. Also, Urea and creatinine levels were found no significant difference between different groups, there was mild increase after chemotherapy but not significant. On other hand, ALT and AST were found no significant difference between healthy control and ALL patients. But their levels were found statistically significant to be increased in ALL patients after chemotherapy compared to before chemotherapy. In conclusion, there are possible link between decreased antioxidants and increased levels of cells alterations due to oxidative damage in ALL, and this appear to be associated with complications of treatment.
\end{abstract}

Keywords Antioxidant, Acute Lymphoblastic Leukemia, Oxidative Stress, Antioxidant Status and Chemotherapy

\section{Introduction}

Acute lymphoblastic Leukemia (ALL) is the most common cancer found in the pediatric population and it accounts for more than $50 \%$ of the hematopoietic malignancies in this age group (Gaynon, 2005). ALL is a disorder caused by an abnormal expression of genes, which is usually a result of chromosomal translocation .The disease can be originated from lymphoid cells of different lineages giving rise to $\mathrm{B}$ or $\mathrm{T}$ cell Leukemia or sometimes mixed -lineage leukemia (Gaynon, 2005).

Production of reactive oxygen species (ROS) is an inevitable result in cells that use aerobic metabolism for energy production (Goto et al., 2007). ROS are known to play a dual role in biological system, since they may be either harmful or beneficial to living systems. Accumulation of such molecules causes noxious effects on individuals, resulting in diseases such as hematopoietic malignancies (Masutani, 2000). Changes in oxidative stress in patients undergoing chemotherapy for ALL have not been well do

* Corresponding author:

drofscience@mail.com (Kholoud Ramadan )

Published online at http://journal.sapub.org/ajmms

Copyright (C) 2011 Scientific \& Academic Publishing. All Rights Reserved cumented the level of DNA oxidized base 8- oxodeoxguanosine in blood mononuclear cells decrease after start of chemotherapy and increase during aggressive chemotherapy in children with ALL.

The effect of reactive species is balanced by the antioxidant action of non-enzymatic antioxidants, as well as by antioxidants enzymes. Antioxidant defenses are extremely important as they represent the direct removal of free radicals, providing maximal protection for biological sites (Valko et al., 2006). The objective of this study was to investigate the oxidative stress markers and some antioxidants status among Acute Lymphoblastic Leukemia patients and find if there is any correlation between the degree of oxidative status and the progression of leukemia

\section{Patients and Methods}

A total of 60 Egyptian patients were included in this study. Consent was obtained by family members of all patients before they participated in the study, which was approved by the ethical committee. They were selected from the National Cancer Institute (NCI). The study included 3 groups of subjects: Group (I): 20 healthy persons. They presented no acute or chronic diseases such as diabetes, 
parasitosis, or any immune dysfunction. Also, the controls used in this study had normal leukocytes and other blood cell counts and made no use of pharmacological therapy; Group (II): 40 patients just diagnosed with ALL patients who had not received any therapy preceding the blood sampling. The diagnosis for ALL based on the following findings: leukocyte count, age, involvement of tissues other than bone marrow, immune pheno typing and responsiveness to the treatment and Group (III): The same of 40 patients of Group (II) after 3 months post-chemotherapy treatment.

All patients were matched for age 5-11 years and sex was divided into 50\% male \& 50\% female. Each studied case was subjected to careful history taking through clinical examination, routine liver profile and routine kidney profile.

Venous blood samples have been collected into three vacationer tubes, one containing EDTA for measurement of blood hemoglobin $(\mathrm{Hb})$, WBC count and reduced glutathione (Beulter et al., 1963). The plasma was separated by centrifugation at $3000 \mathrm{rpm}$ for 15 minutes. Plasma ascorbic acid was estimated using kit supplied from Biodiagnostic, according to Harris and Ray (1935). Plasma Glutathione reductase (Goldberg \& Spooner, 1983) and Catalase (Aebi, 1984) concentrations were determined using commercially available Biodiagnostic assay kit. Erythrocytes (red blood cells) were lysed in 4 times its volume of ice cold HPLC grade water. The supernatant (erythrocyte lysate) was used for the determination of SOD (Nishikimi et al., 1972) and GST (Habig et al., 1974).

The clotted blood was centrifuged and the serum was separated. The fresh serum was used for the determination of malondialdehyde (Ohkawa et al., 1979) and 8dG (Trevigen Elisa kit). The level of serum Creatinine and urea were measured spectrophotometrically by the method described by (Schirmeister et al, 1964 and Fawcett \& Soctt, 1960). Serum AST and ALT concentration were estimated using commercially available Randox kit (Bergmeyer).

Bone marrow aspiration slides, freshly prepared were used for lymphoblast examination.

Statistical Analysis: Data was expressed as the mean \pm S.D. Statistical analysis was performed with Statistical Package for the Social Science for Windows (SPSS, version 10.0, 1999, Chicago, IL, USA). Differences between groups were analyzed by one-way analysis of variance (ANOVA). Pearson's correlation analysis was performed to determine the relationships between nitric oxide, uric acid and other cardiovascular risk variables. $\mathrm{P}$-value $<0.05$ was accepted to indicate statistical significance.

\section{Results}

The demographic and the hematological data of ALL patients and control are shown in Table 1. It was found that the levels of WBCs and Lymphoblasts were significantly elevated in diagnosed leukemic patients before chemotherapy compared to control group $(\mathrm{P}<0.05)$, while $\mathrm{Hb}$ was significantly decreased $(\mathrm{P}<0.05)$. The levels of $\mathrm{Hb}$, WBCs and Lymphoblasts were significantly decreased in the same diagnosed leukemic patients after chemotherapy compared to diagnosed leukemic patients before chemotherapy group $(\mathrm{P}<0.05)$. The results indicate that hematologic data may correlate to the severity of leukemia. Also, our results show that the levels of MDA and $8 \mathrm{dG}$ were significantly elevated in diagnosed leukemic patients before chemotherapy compared to control group $(\mathrm{P}<0.05)$. The level of MDA was significantly decreased in the same diagnosed leukemic patients after chemotherapy as compared to diagnosed leukemic patients before chemotherapy group $(\mathrm{P}<0.05)$. While the level $8 \mathrm{dG}$ was significantly increased (Table 2 ).

Table 1. Demographic and hematological data of different studied groups (Mean \pm S.D)

\begin{tabular}{|c|c|c|c|}
\hline $\begin{array}{l}\text { Groups } \\
\text { Parameters }\end{array}$ & $\begin{array}{l}\text { Group I } \\
(\mathrm{n}=20)\end{array}$ & $\begin{array}{c}\text { Group II } \\
(\mathrm{n}=40)\end{array}$ & $\begin{array}{c}\text { Group III } \\
(\mathrm{n}=40)\end{array}$ \\
\hline $\begin{array}{l}\text { Age (years) } \\
\text { Mean } \pm \text { SD } \\
\text { range }\end{array}$ & $\begin{array}{c}7.6 \pm 1.4 \\
(5-11)\end{array}$ & $\begin{array}{c}8.2 \pm 2.0 \\
(5-11)\end{array}$ & $\begin{array}{c}8.45 \pm 2.0 \\
(5.25-11.25)\end{array}$ \\
\hline $\begin{array}{l}\mathrm{Hb}(\mathrm{gm} / \mathrm{dl}) \\
\text { Mean } \pm \mathrm{SD} \\
\text { range }\end{array}$ & $\begin{array}{c}12.5 \pm 5.4 \\
(11.5-13.5)\end{array}$ & $\begin{array}{c}9.9 \pm 4.8^{\mathrm{a}} \\
(7.6-11.9)\end{array}$ & $\begin{array}{c}6.1 \pm 4.7^{b} \\
(5.2-9)\end{array}$ \\
\hline $\begin{array}{c}\text { WBCs }(【 10 】 \\
3 c e l 1 / \mathrm{ml}) \\
\text { Mean } \pm \text { SD } \\
\text { range }\end{array}$ & $\begin{array}{c}6.572 \pm 1.797 \\
(3.9-10.78)\end{array}$ & $\begin{array}{l}26.701 \pm 1.018^{\mathrm{a}} \\
(24.345-28.95)\end{array}$ & $\begin{array}{l}8.851 \pm 0.375^{\mathrm{b}} \\
(8.100-9.57)\end{array}$ \\
\hline $\begin{array}{c}\text { Lymphoblasts } \\
(\%) \\
\text { Mean } \pm \text { SD } \\
\text { range }\end{array}$ & $\begin{array}{l}1 \pm 0.17 \\
(0-1.2)\end{array}$ & $\begin{array}{c}79.9 \pm 2.8^{\mathrm{a}} \\
(73-85)\end{array}$ & $\begin{array}{c}7.7 \pm 0.46^{\mathrm{b}} \\
(6-8)\end{array}$ \\
\hline
\end{tabular}

$\mathrm{P}^{\mathrm{a}}<0.05$ is significant difference as compared to G I, $\mathrm{P}^{\mathrm{b}}<0.05$ is significant difference as compared to G II.

Table 2. Serum levels of MDA and $8 \mathrm{dG}$ in different studied groups (Results are expressed as mean $\pm \mathrm{SD}$ )

\begin{tabular}{|c|c|c|c|}
\hline $\begin{array}{c}\text { Groups } \\
\text { Parameters }\end{array}$ & $\begin{array}{c}\text { Group I } \\
(\mathrm{n}=20)\end{array}$ & $\begin{array}{c}\text { Group II } \\
(\mathrm{n}=40)\end{array}$ & $\begin{array}{c}\text { Group III } \\
(\mathrm{n}=40)\end{array}$ \\
\hline $\begin{array}{c}\text { MDA }(\mathrm{nmol} / \mathrm{ml}) \\
\text { Mean } \pm \mathrm{SD} \\
\text { range }\end{array}$ & $\begin{array}{c}7.42 \pm 0.36 \\
(6.9-8.13)\end{array}$ & $\begin{array}{l}13.14 \pm 0.48^{\mathrm{a}} \\
(12-14.5)\end{array}$ & $\begin{array}{l}9.99 \pm 0.46^{\mathrm{b}} \\
(9.1-11.05)\end{array}$ \\
\hline $\begin{array}{c}8 \mathrm{dG}(\mathrm{ng} / \mathrm{ml}) \\
\text { Mean } \pm \mathrm{SD} \\
\text { range }\end{array}$ & $\begin{array}{c}0.24 \pm 0.011 \\
(0.22-0.26)\end{array}$ & $\begin{array}{c}2.28 \pm 0.14^{\mathrm{a}} \\
(2-2.5)\end{array}$ & $\begin{array}{l}4.6 \pm 0.41^{\mathrm{b}} \\
(4-5.47)\end{array}$ \\
\hline
\end{tabular}

S.D $=$ Standard Deviation. pa $<0.05$ is significant difference as compared to $\mathrm{G}$ I, $\mathrm{pb}<0.05$ is significant difference as compared to G II

Table (3) shows the antioxidants status in different studied groups. The levels of SOD, VIT.C, GST GR, GSH and CAT were significantly decreased in diagnosed leukemic patients before and after chemotherapy compared to control and diagnosed leukemic patients before chemotherapy group respectively $(\mathrm{P}<0.05)$.

There were no statistically significant difference $(\mathrm{P}>$ 0.05 ) between the diagnosed leukemic patients before chemotherapy compared to control group $(\mathrm{P}>0.05)$ as regards plasma creatinine, urea, GPT and GOT (Table 3). Also, there were no significant difference in the same diagnosed leukemic patients after chemotherapy compared to diagnosed leukemic patients before chemotherapy group $(\mathrm{P}>0.05)$, but the levels of ALT and AST were significantly 
increased after chemotherapy compared to diagnosed leukemic patients before chemotherapy group $(\mathrm{P}<0.05)$. The results indicate that effect of chemotherapy may correlate to the severity of liver damage.

Table 3. Blood antioxidants status in different studied groups

\begin{tabular}{|c|c|c|c|}
\hline $\begin{array}{c}\text { Groups } \\
\text { Parameters }\end{array}$ & $\begin{array}{c}\text { Group I } \\
(\mathrm{n}=20)\end{array}$ & $\begin{array}{c}\text { Group II } \\
(\mathrm{n}=40)\end{array}$ & $\begin{array}{c}\text { Group III } \\
(\mathrm{n}=40)\end{array}$ \\
\hline $\begin{array}{c}\text { GSH(mg/dl) } \\
\text { Mean } \pm \text { SD } \\
\text { Range }\end{array}$ & $\begin{array}{c}29.4 \pm 1.4 \\
(27.4-31.8)\end{array}$ & $\begin{array}{c}22.8 \pm 1.07^{\mathrm{a}} \\
(21-24)\end{array}$ & $\begin{array}{c}15.25 \pm 0.65^{\mathrm{b}} \\
(14-16)\end{array}$ \\
\hline $\begin{array}{c}\text { GST(U/dl) } \\
\text { Mean } \pm \mathrm{SD} \\
\text { Range }\end{array}$ & $\begin{array}{c}81.5 \pm 2.2 \\
(76.2-84.7)\end{array}$ & $\begin{array}{c}62.2 \pm 3^{\mathrm{a}} \\
(53.7-67.4)\end{array}$ & $\begin{array}{c}45.6 \pm 1.8^{\mathrm{b}} \\
(42.1-48.2)\end{array}$ \\
\hline $\begin{array}{c}\text { GR(U/L) } \\
\text { Mean } \pm \mathrm{SD} \\
\text { Range }\end{array}$ & $\begin{array}{c}58 \pm 2.7 \\
(55-62)\end{array}$ & $\begin{array}{c}35.7 \pm 1.7^{\mathrm{a}} \\
(31-37.4)\end{array}$ & $\begin{array}{c}19.3 \pm 0.8^{\mathrm{b}} \\
(18-20.6)\end{array}$ \\
\hline $\begin{array}{c}\text { CAT(U/L) } \\
\text { Mean } \pm \mathrm{SD} \\
\text { Range }\end{array}$ & $\begin{array}{c}14.3 \pm 0.42 \\
(13.7-15)\end{array}$ & $\begin{array}{c}8.2 \pm 0.4^{\mathrm{a}} \\
(7.6-9)\end{array}$ & $\begin{array}{c}6.3 \pm 0.3^{\mathrm{b}} \\
(5.6-7.1)\end{array}$ \\
\hline $\begin{array}{c}\mathrm{VIT} . \mathrm{C}(\mathrm{mg} / \mathrm{l}) \\
\text { Mean } \pm \mathrm{SD} \\
\text { Range }\end{array}$ & $\begin{array}{c}8.2 \pm 0.39 \\
(7.25-9)\end{array}$ & $\begin{array}{c}7.35 \pm 0.44^{\mathrm{a}} \\
(6.5-8.4)\end{array}$ & $\begin{array}{c}6.2 \pm 0.4^{\mathrm{b}} \\
(5.7-7)\end{array}$ \\
\hline $\begin{array}{c}\mathrm{SOD}(\mathrm{U} / 10 \mathrm{mg} \\
\text { Hb) }\end{array}$ & $\begin{array}{c}25.38 \pm 0.65 \\
\text { Mean } \pm \mathrm{SD} \\
\text { Range }\end{array}$ & $\begin{array}{c}22.85 \pm 1.12^{\mathrm{a}} \\
(24.33-26.22)\end{array}$ & $\begin{array}{c}(20.37-24.22) \\
\left(15.28 \pm 0.68^{\mathrm{b}}\right.\end{array}$ \\
\hline
\end{tabular}

S.D $=$ Standard Deviation. pa $<0.05$ is significant difference as compared to $\mathrm{G} \mathrm{I}, \mathrm{pb}<0.05$ is significant difference as compared to G II

Pearson's correlation analysis represented in Table (4) revealed that, serum MDA was positively correlated with serum $8 \mathrm{dG}(\mathrm{r}=0.59, \mathrm{p}<0.05)$ and negatively correlated with GSH, SOD, GR, CAT, VIT.C and $\mathrm{Hb}(\mathrm{r}=-0.70,-0.63,-0.60$, $-0.65,-0.73$ and -0.59 respectively, $p<0.05$ ), also $8 \mathrm{dG}$ was negatively correlated with GSH,SOD,GR,CAT and VIT.C $(\mathrm{r}=-0.61,-0.52,-0.55,-0.50$, and -0.59 respectively, $\mathrm{p}<0.05)$, while GSH was positively correlated with SOD, GR ,CAT and $\mathrm{Hb}(\mathrm{r}=0.56,0.76,0.72$ and 0.63 respectively, $\mathrm{p}<0.05)$, also there was a positive correlation between GST\&VIT.C $(\mathrm{r}=0.55, \mathrm{p}<0.05)$ and $\mathrm{GR} \& \mathrm{CAT}(\mathrm{r}=0.73, \mathrm{p}<0.05)$.

Table 4. Kidney and Liver profiles in different studied groups (results are expressed as mean $\pm \mathrm{SD}$ )

\begin{tabular}{|c|c|c|c|}
\hline Groups & $\begin{array}{c}\text { Group I } \\
\mathrm{n}=20\end{array}$ & $\begin{array}{c}\text { Group II } \\
\mathrm{n}=40\end{array}$ & $\begin{array}{c}\text { Group III } \\
\mathrm{n}=40\end{array}$ \\
\hline $\begin{array}{c}\mathrm{CREAT} \text {.(mg/dl) } \\
\text { Mean } \pm \mathrm{SD} \\
\text { range }\end{array}$ & $\begin{array}{c}0.47 \pm 0.06 \\
(0.4-0.6)\end{array}$ & $\begin{array}{c}0.47 \pm 0.09 \\
(0.41-0.74)\end{array}$ & $\begin{array}{c}0.49 \pm 0.12 \\
(0.43-0.77)\end{array}$ \\
\hline $\begin{array}{c}\mathrm{UREA}(\mathrm{mg} / \mathrm{dl}) \\
\text { Mean } \pm \mathrm{SD} \\
\text { range }\end{array}$ & $\begin{array}{c}15.6 \pm 4.35 \\
(10-22)\end{array}$ & $\begin{array}{c}17.12 \pm 4.8 \\
(11-27)\end{array}$ & $\begin{array}{c}19.55 \pm 4.9 \\
(12-28)\end{array}$ \\
\hline $\begin{array}{c}\text { GPT(U/L) } \\
\text { Mean } \pm \mathrm{SD} \\
\text { range }\end{array}$ & $\begin{array}{c}19.25 \pm 4.15 \\
(14-24)\end{array}$ & $\begin{array}{c}22.02 \pm 1.02 \\
(21-24)\end{array}$ & $\begin{array}{c}98.5 \pm 6.02^{\mathrm{b}} \\
(90-111)\end{array}$ \\
\hline $\begin{array}{c}\text { GOT(U/L) } \\
\text { Mean } \pm \mathrm{SD} \\
\text { range }\end{array}$ & $\begin{array}{c}23.35 \pm 4.03 \\
(17-25)\end{array}$ & $\begin{array}{c}23.82 \pm 0.95 \\
(22-26)\end{array}$ & $\begin{array}{c}103.95 \pm 4.95^{\mathrm{b}} \\
(95-114)\end{array}$ \\
\hline
\end{tabular}

S.D $=$ Standard Deviation. pa $<0.05$ is significant difference as compared to $\mathrm{G} \mathrm{I}, \mathrm{pb}<0.05$ is significant difference as compared to G II

Table 5. The significant correlation analysis between measured parameters of diagnosed leukemic patients before chemotherapy

\begin{tabular}{|c|c|c|c|c|c|c|c|c|c|c|}
\hline & BLASTS & WBCS & VIT.C & CAT & GR & GST & SOD & GSH & 8DG & MDA \\
\hline 8DG & & & & & & & & & & $0.77^{*}$ \\
\hline GSH & & & & & & & & & $-0.62 *$ & $-0.82 *$ \\
\hline SOD & & & & & & & & $0.69 *$ & $-0.6^{*}$ & $-0.70^{*}$ \\
\hline GST & & & & & & & 0.4 & 0.35 & -0.34 & -0.3 \\
\hline GR & & & & & & 0.43 & $0.69^{*}$ & $0.58 *$ & -0.51 & $-0.75^{*}$ \\
\hline CAT & & & & & $0.57 *$ & 0.43 & $0.61 *$ & $0.72 *$ & -0.58 & $-0.71 *$ \\
\hline VIT.C & & & & $0.51 *$ & $0.52^{*}$ & 0.26 & 0.46 & $0.47 *$ & -0.53 & $-0.69^{*}$ \\
\hline WBCs & & & $-0.55 *$ & $-0.62 *$ & $-0.6^{*}$ & -0.41 & $-0.56^{*}$ & $-0.64 *$ & $0.64 *$ & $0.80^{*}$ \\
\hline BLASTs & & $0.7^{*}$ & $-0.57 *$ & $-0.6^{*}$ & $-0.62 *$ & -0.39 & $-0.55^{*}$ & $-0.55^{*}$ & $0.73^{*}$ & $0.68^{*}$ \\
\hline GPT & 0.2 & 0.15 & $-0.57 *$ & $-0.56^{*}$ & $-0.6^{*}$ & 0.4 & $-0.6^{*}$ & $-0.68 *$ & 0.5 & 0.39 \\
\hline GOT & 0.18 & 0.22 & $-0.54 *$ & -0.4 & -0.38 & -0.2 & -0.4 & $-0.51 *$ & 0.36 & 0.41 \\
\hline UREA & -0.1 & -0.2 & 0.12 & -0.01 & 0.08 & 0.03 & -0.05 & 0.06 & -0.09 & -0.17 \\
\hline CREAT. & 0.01 & -0.04 & 0.02 & -0.12 & -0.12 & -0.04 & -0.03 & -0.09 & 0.25 & -0.02 \\
\hline HB & -0.31 & -0.42 & 0.32 & $0.51 *$ & $0.58^{*}$ & 0.43 & $0.79 *$ & $0.77 *$ & $-0.64 *$ & $-0.58^{*}$ \\
\hline
\end{tabular}

*Significant correlation between parameters in pre-chemotherapy group at $\mathrm{P}<0.05$.

Table 6. Correlation coefficient between measured parameters of healthy control

\begin{tabular}{|c|c|c|c|c|c|c|c|c|c|}
\hline & WBCS & VIT.C & CAT & GR & GST & SOD & GSH & 8DG & MDA \\
\hline 8DG & & & & & & & & & $0.59 *$ \\
\hline GSH & & & & & & & & $-0.61 *$ & $-0.70 *$ \\
\hline SOD & & & & & & & $0.56^{*}$ & $-0.52 *$ & $-0.63 *$ \\
\hline GST & & & & & & 0.31 & 0.49 & -0.46 & -0.48 \\
\hline GR & & & & & 0.28 & $* 0.42$ & $* 0.76$ & $-0.55 *$ & $0.60 *$ \\
\hline CAT & & & & $* 0.73$ & 0.21 & 0.46 & $* 0.72$ & $-0.50 *$ & $-0.65 *$ \\
\hline VIT.C & & & 0.34 & 0.45 & $* 0.55$ & 0.5 & 0.39 & $-0.59 *$ & $-0.73 *$ \\
\hline WBCs & & -0.25 & 0.04 & 0.08 & -0.32 & -0.16 & 0.08 & -0.04 & -0.07 \\
\hline GPT & -0.02 & 0.20 & 0.25 & -0.34 & 0.23 & 0.28 & -0.34 & 0.49 & 0.40 \\
\hline GOT & 0.04 & -0.39 & -0.36 & -0.49 & -0.33 & 0.34 & -0.47 & 0.54 & 0.48 \\
\hline UREA & -0.29 & 0.07 & 0.17 & 0.05 & 0.15 & 0.06 & 0.08 & 0.007 & 0.09 \\
\hline CREAT. & 0.31 & 0.11 & 0.07 & 0.01 & 0.15 & -0.23 & -0.02 & 0.17 & -0.06 \\
\hline HB & -0.22 & -0.17 & 0.019 & 0.15 & $0.52 *$ & $0.56 *$ & $0.63 *$ & 0.17 & $-0.59 *$ \\
\hline
\end{tabular}

*Significant correlation between parameters in control group at $\mathrm{P}<0.05$. 
In group II (pre-chemotherapy), MDA was positively correlated with $8 \mathrm{dG}$, WBCs and lymphoblasts $(\mathrm{r}=0.77,0.80$ and $0.68, \mathrm{p}<0.05)$, but MDA was negatively correlated with GSH, SOD, GR, CAT, VIT.C and HB ( $\mathrm{r}=-0.82,-0.70$, $-0.75,-0.71,-0.69$ and -0.58 respectively, $\mathrm{p}<0.05)$. Also $8 \mathrm{dG}$ was positively correlated with ,WBCS, lymphoblasts and GPT $(\mathrm{r}=0.64,0.73$ and $0.50, \mathrm{p}<0.05)$, while $8 \mathrm{dG}$ was negatively correlated with GSH, SOD, GR, CAT,VIT.C and HB $(r=-0.62,-0.60,-0.51,-0.58,-0.53$ and -0.64 respectively, $\mathrm{p}<0.05)$, while GSH was positively correlated with SOD, GR ,CAT and HB ( $\mathrm{r}=0.69,0.58,0.72$ and 0.77 respectively, $\mathrm{p}<0.05$ ) but GSH was negatively correlated with WBCS and lymphoblasts $(r=-0.64$ and- 0.55 respectively, $\mathrm{p}<0.05)$. The results also showed a positive correlation between SOD and GR, CAT and $\mathrm{Hb}(\mathrm{r}=0.69,0.61$, and 0.79 respectively, $\mathrm{p}<0.05$ ).

\section{Discussion}

Leukemia's are the most common childhood cancer, representing approximately $31 \%$ of all cancer cases occurring in children under the age of 15 years. Acute lymphoblastic leukemia (ALL) represents approximately $75 \%$ of all leukemia's within this age group, whereas acute myeloid leukemia (AML) accounts for 20\% (Jemal et al., 2006).

This study was carried out on 60 Egyptian children of the same age groups, 50\% male and 50\% female: group I comprised 20 healthy children, grout II comprised 40 children just diagnosed with ALL and group III comprised the same 40 children of group II after 3 months of chemotherapy treatment.

Leukocytes count and lymphoblast level were found statistically significant to be increased in ALL patients compared to controls. This finding must be indicating presence the disease (Escherich et al., 2010).

Leukocytes count and lymphoblast level were statistically significant to be decreased in ALL patients after chemotherapy compared to before chemo- therapy (Eyrich et al., 2009 ), these studies are harmony with the results of the present study which showed that Leukocytes count and lymphoblast level in acute lymphoblastic leukemic patients were significantly increased $(p<0.05)$ as compared to that of ALL patients after chemotherapy, this indicate to complete remission, then its levels are more decrease as compared to control healthy children due to absence of disease.

$\mathrm{Hb}$ was found statistically significant to be decreased in ALL patients compared to controls. This finding may indicate a possible link between decreased $\mathrm{Hb}$ and decreased levels of GSH, GST and SOD result to oxidative damage, supporting the idea that there is a persistence of oxidative stress leading to cellular dysfunction and cell death. Accumulation of such molecules causes noxious effects on individuals, resulting in diseases such as hematopoietic malignancies such as acute lymphoblastic leukemia (He et al., 2009).

$\mathrm{Hb}$ level was found statistically significant to be de- creased in ALL patients after chemotherapy compared to before chemo- therapy (Zou et al., 2010). These studies are harmony with the results of the present study which showed that $\mathrm{HB}$ in acute lymphoblastic leukemic patients was significantly decreased ( $p<0.05$ ) as compared to that of control healthy children then its level is more decrease after chemotherapy, this indicate there is correlation between anemic ALL patients and decrease of some antioxidants level .

In this study plasma malondialdehyde (MDA) was studied as a marker of oxidative stress and lipid peroxidation. The level of MDA contents were shown to be increased in the just diagnosed patients, when compared with the control group. These results are in accordance with the increase of MDA in the serum of patients with chronic leukemia and ALL and of bone marrow transplant recipients (Battisti et al., 2008). Also, significant decrease in plasma MDA was observed in ALL patients after chemotherapy $(p<0.05)$ as compared to that of ALL patients before chemotherapy that agree with Sharma et al., 2008 might be due to the death of tumor cells.

The results may indicate a possible link between decreased activities of antioxidant enzymes and increased levels of oxidative damage, and support the notion that free radical reactions may be increased in malignant cells.

Serum 8-hydroxy-2-desoxyguanosine (8dG) was studied as a marker of oxidative stress. $8 \mathrm{dG}$ is a well-recognized biomarker of DNA damage, there was statistically significant increase in $8 \mathrm{dG}$ level in ALL patients compared to controls, such as $8 \mathrm{dG}$ have previously observed in patients with ALL the results of the $8 \mathrm{dG}$ levels were higher in the active phase of disease We observed a direct correlation with peripheral leukocyte counts and MDA levels (Yang et al., 2009), these studies are harmony with the results of the present study which showed that serum 8-dG of acute lymphoblastic leukemic patients was significantly elevated ( $p$ $<0.05$ ) as compared to that of control healthy children.

8-dG serum levels were two-fold higher in patients after treatment than before treatment and three-fold higher than in controls, High serum levels of $8-\mathrm{dG}$ in patients after chemotherapy may be due to a direct effect of chemotherapy on liver, muscle and skin epidermal cells. On chemotherapy could be a sensitive follow-up biomarker of DNA oxidation, these studies agree with the results of the present study which showed that serum levels of $8-\mathrm{dG}$ of acute lymphoblastic leukemic patients was significantly elevated $(p<0.05)$ as compared to that of control healthy children then its level more increase after chemotherapy (Georgala et al., 2005).

In this study, it was demonstrated that SOD, GST, GR, CAT activities were reduced in just diagnosed ALL patients and patients after treatment. This phenomenon indicates a disturbance of the protective role of these enzymes against free radicals in ALL. These findings are in accordance with earlier studies of He et al., 2009 who confirmed decreased SOD and CAT activities in the lymphocytes of chronic lymphocytic leukemia (CLL) patients. The results are also 
in agreement with the reports of Sentuerker et al., 1997, demonstrated reduced CAT and SOD activities in the lymphocytes of ALL patients. However, taken together, these findings suggest that there are alterations in the enzymatic antioxidant defenses, which can interfere in the direct removal of free radicals and in the protection for biological sites.

Oxidative stress induces a cellular Redox imbalance which has been found to be present in various cancer cells. The effect of reactive oxygen and nitrogen species is balanced by antioxant enzymes such as CAT and SOD. The impairment antioxidant role of CAT and SOD may support the accumulation of free radicals. Alternatively, it is possible that the antioxidant system is impaired as a consequence of an abnormality in the antioxidative metabolism due to the cancer process. This effect could be enhanced by the characteristic increase in the production of $\mathrm{H} 2 \mathrm{O} 2$ by the cancer cells (Battisi et al., 2008).

Our findings revealed that the levels of glutathione (GSH) was statistically significant decreased in just diagnose ALL patients and in treatment group compared to controls. This finding may indicate a possible link between decreased GSH and increased levels of cells alterations due to oxidative damage, supporting the idea that there is a persistence of oxidative stress in acute lymphoblastic leukemia. (Papiez et al., 2009). The decrease in thiol levels may represent a depletion of this antioxidant due to high concentrations of $\mathrm{H} 2 \mathrm{O} 2$ and other peroxides formed in tumor cells. Therefore, thiols levels are not sufficient to prevent oxidative stress in the affected cells.

With respect to Vitamin C levels (VIT.C) in plasma, it was demonstrated that Vit. C was statistically significant to be decreased in both just diagnosed ALL patients and patients after treatment compared to controls. These studies are harmony with the results of Neyestani et al., (2007)

In the present study, serum urea and Creatinine levels were none significantly different in the three studied groups, there is mild increase after chemotherapy but not significant, this indicate that chemotherapy is not directly tubulotoxic. Its side effects on glomeruli are usually without clinical relevance. These results agreed with Hempel et al., 2003 who found no significant differences in serum urea and Creatinine between ALL patients and control.

With respect to the ALT and AST levels in serum, no significant difference was observed between healthy control group and ALL patients group, but ALT and AST levels were found statistically significant to be increased in ALL patients after chemotherapy compared to before chemotherapy. The findings are in agreement with those found by other studies (Zou et al., 2010).

All the disorders suggested that liver, renal and hematological systems might be the target effectors of toxic effect induced by chemotherapy such as increase in plasma ALT,AST and decrease in hepatic glutathione (GSH), (Zou et al., 2010 ; Kour et al., 2010).

The correlation analysis showed that there was a positive correlation between MDA and 8dG $(\mathrm{r}=0.59, \mathrm{p}<0.05)$ but MDA was negatively correlated with GSH, SOD, GR, CAT, VIT.C and $\mathrm{Hb}(\mathrm{r}=-0.70,-0.63,-0.60,-0.65,-0.73$ and -0.59 respectively, $\mathrm{p}<0.05$ ), while GSH was positively correlated with SOD, GR ,CAT and $\mathrm{Hb}(\mathrm{r}=0.56,0.76,0.72$ and 0.63 respectively, $\mathrm{p}<0.05$ ), also there was a positive correlation between GST\&VIT.C $(r=0.55, p<0.05)$ and GR\&CAT $(\mathrm{r}=0.73, \mathrm{p}<0.05)$. In group II(pre-chemotherapy), MDA was positively correlated with $8 \mathrm{dG}$,WBCs and lymphoblasts ( $\mathrm{r}=0.77,0.80$ and $0.68, \mathrm{p}<0.05)$, but MDA was negatively correlated with GSH, SOD, GR, CAT, VIT.C and HB $(\mathrm{r}=-0.82,-0.70,-0.75,-0.71,-0.69$ and -0.58 respectively, $\mathrm{p}<0.05$ ). Also $8 \mathrm{dG}$ was positively correlated with, WBCS , lymphoblasts and GPT( $r=0.64,0.73$ and $0.50, p<0.05)$, while $8 \mathrm{dG}$ was negatively correlated with GSH, SOD, GR, CAT, VIT.C and HB $(\mathrm{r}=-0.62,-0.60,-0.51,-0.58,-0.53$ and -0.64 respectively, $p<0.05$ ), while GSH was positively correlated with SOD, GR ,CAT and HB ( $\mathrm{r}=0.69,0.58,0.72$ and 0.77 respectively, $\mathrm{p}<0.05)$. In conclusion, the present work provides evidence for the increased levels of oxidative damage and decreased levels of the antioxidant system in ALL patients, suggesting a possible link between these two important parameters in this type of cancer. More studies are necessary to confirm whether these alterations are the cause or the consequence of carcinogenesis.

\section{REFERENCES}

[1] Aebi H (1984): "Catalase in vitro". Meth. Enzymol. 105: $121-6$

[2] Battisti V, Maders LD, Bagatini MD, Santos KF, Spanevello M, Maldonado PA, Brulé AO,Araújo Mdo C, Schetinger MR, Morsch VM. (2008): Measurement of oxidative stress and antioxidant status in acute lymphoblastic leukemia patients. Clin Biochem.vol.41: 511-518

[3] Escherich G, Horstmann MA, Zimmermann M, Janka-Schaub GE(2010): Cooperative study group for childhood acute lymphoblastic leukaemia (COALL): long-term results of trials 82,85,89,92 and 97.Leukemia. 24(2):298-308

[4] Eyrich M, Wiegering V, Lim A, Schrauder A, Winkler B, Schlegel PG.(2009): Immune function in children under chemotherapy for standard risk acute lymphoblastic leukaemia - a prospective study of 20 pediatric patients. Br J Haematol. 147(3):360-70

[5] Gaynon p (2005): Childhood acute lymphocytic leukemia and relapse. Br J Haematol 131 pp.579-587

[6] Georgala, Sophia, Papassotiriou, Ioannis, Georgala, Catherina, Demetriou, Elisabeth, Schulpis, Kleopatra H. (2005): isotretinoin therapy induces DNA oxidative damage. Genetics and molecular diagnostics. Clinical chemistry \& laboratory medicine. 43(11):1178-1182

[7] Goto H, Yanagimachi M, Kajiwara R and Yokota S (2007): Lack of mitochondrial depolarization by oxidative stress is associated with resistance to buthionine sulfoximine in acute lymphocytic leukemia cells. Leuk Res 31pp. 1301-1309 
[8] Habig WH, Pabst MJ, Fleischner G, Gatmaitan Z, Arias IM, Jakoby WB (1974): "The identity of glutathione S-transferase B with ligandin, a major binding protein of liver". Proc. Natl. Acad. Sci. U.S.A. 71 (10): 3879-82

[9] He YL, Cao LZ, Yang J, Yang MH, Xu WQ, Xie M, Shi Z. (2009): [Expression of WAVE1 and p22phox in children with acute lymphocytic leukemia and the relationship of WAVE1 with oxidative stress] Zhongguo Dang Dai Er Ke Za Zhi. (2):88-92

[10] Hempel L, Misselwitz J, Fleck C, Kentouche K, Leder C, Appenroth D, Rost M, Zintl F(2003 ): Influence of high-dose methotrexate therapy (HD-MTX) on glomerular and tubular kidney function. Med Pediatr Oncol. 40(6):348-54

[11] Jemal A, Siegal R, Ward E, MurrayT, Xu J, Smigal C. (2006): CA A Cancer Statistics, 2006 Kour K, Pandey A, Suri KA, Satti NK, Gupta KK, Bani S(2010): Restoration of stress-induced altered $\mathrm{T}$ cell function and corresponding cytokines patterns by Withanolide A. Int Immunopharmacol. 9(10):1137-44.

[12] Masutani h (2000): Oxidative stress response and signaling in hematological malignancies and HIV infection. Int $\mathrm{J} \mathrm{He}$ motol 71pp25-32

[13] Neyestani TR, Fereydouni Z, Hejazi S, Salehi-Nasab F, Nateghifard F, Maddah M, Karandish M. (2007): Vitamin C status in Iranian children with acute lymphoblastic leukemia: evidence for increased utilization. J Pediatr Gastroenterol
Nutr. 45(1):141-4

[14] Papiez MA, Malgorzata Dybala, Magdalena Sowa-Kucma, Wirginia Krzysciak, Hevidar M. Taha, Alicja, Gabriel Nowak, (2009): Evaluation of oxidative status and depression-like responses in Brown Norway rats with acute myeloid leukemia, Neuro-Psychopharmacology \& Biological Psychiatry: 10-16

[15] Sentürker S, Karahalil B, Inal M, Yilmaz H, Müslümanoglu H, Gedikoglu G, Dizdaroglu M. (1997): Oxidative DNA base damage and antioxidant enzyme levels in childhood acute lymphoblastic leukemia. FEBS Lett. ; 416(3):286-90

[16] Sharma A, Rajappa M, Saxena A, Sharma M.(2008): Antioxidant status in advanced cervical cancer patients undergoing neoadjuvant chemoradiation. Br J Biomed Sci. 2007; 64(1):23-7

[17] Valko M, Rhodes C, Monocola M and Mazura M (2006): Free radicals, metals and antioxidants in oxidative stress-induced cancer. Chem. Boil Interact 160 pp. 1 - 40

[18] Yang Y, Tian Y, Yan C, Jin X, Tang J, Shen X. (2009): Determinants of urinary 8-hydroxy-2'-deoxyguanosine in Chinese children with acute leukemia. Environ Toxicol. (5):446-52

[19] Zou Y, Zhang X, Mao Y, Lu G, Huang M, Yuan B(2010): Acute toxicity of a single dose DATR, recombinant soluble human TRAIL mutant, in rodents and crab-eating macaques. Hum Exp Toxicol 